Winter 2008

\title{
Democratization: The Contribution of Fair Trade and Ethical Trading Movements
}

Janet Dine

Queen Mary College

Follow this and additional works at: https://www.repository.law.indiana.edu/ijgls

Part of the Civil Law Commons, International Law Commons, and the International Trade Law

\section{Commons}

\section{Recommended Citation}

Dine, Janet (2008) "Democratization: The Contribution of Fair Trade and Ethical Trading Movements," Indiana Journal of Global Legal Studies: Vol. 15 : Iss. 1 , Article 8.

Available at: https://www.repository.law.indiana.edu/ijgls/vol15/iss1/8

This Symposium is brought to you for free and open access by the Law School Journals at Digital Repository @ Maurer Law. It has been accepted for inclusion in Indiana Journal of Global Legal Studies by an authorized editor of Digital Repository @ Maurer Law. For more information, please contact rvaughan@indiana.edu.

\section{$\Psi$}

JEROME HALL LAW LIBRARY

INDIANA UNIVERSITY

Maurer School of Law
Blooming ton 


\title{
Democratization: the Contribution of Fair Trade and Ethical Trading Movements
}

\author{
JANet Dine
}

Abstract

De-democratization and institutional corruption threaten equality among the expanding global market community. International treaties have been largely unsuccessful because they are designed to favor the more politically and economically advantaged players. In addition to meeting these challenges, there are many additional benefits to be gained from adopting the principles of the Fair Trade and Ethical Trading movements. Finally, international law has an obligation to integrate the principles of social and ethical trading movements to prevent the autonomous powers and transnational corporations from dominating the traditional, less powerful markets and so that welfare increases for all.

\section{INTRODUCTION}

The Fair Trade movement has recently entered into mainstream trade. The global sales of all fair trade products amounted to approximately $£ 500$ million (approximately $\$ 800$ million) in 2003 . Since then annual growth rates have been about 30 percent; total sales were $\$ 1$ billion in 2005. This prompted the Economist to ask, "Has the supermarket trolley replaced the ballot box?" 2 The article's answer was "no" but the question posed raises a complex issue. The social movements have championed fair trade as a contribution to "bottom-up" democracy and as a challenge to the prevailing international economic order. Fair trade is also a popular way for consumers to express solidarity with those who work in poor countries and who are particularly badly served by the system of "free trade" which has been constructed

\footnotetext{
* Janet Dine, Director, Centre for Commercial Law Studies, Queen Mary College, London. Thanks are due to Dr. Michael Blecher for comments on an earlier draft of this paper.

1. Anja Osterhaus, World Trade Contradictions and the Fair Trade Response, in Business UNusual: Success and Challenges of Fair Trade 29-48 (2006).

2. Voting with Your Trolley, EсONOMIst, Dec. 9, 2006, § 2.
} 
by the powerful among the international community. The Fair Trade movement operates on a number of principles with a general aim of relieving poverty. Space prevents a full discussion of the principles here, but two of the most important are the pledge to provide a purchase price for commodities above the price of production at all times despite the fluctuations of the global market and the pledge to provide pre-finance for producers. In both cases these mechanisms are widely unavailable as a result of the liberalization of markets under international trade rules. ${ }^{3}$

\title{
I. Fair Trade and the Social Movements
}

In the specific context of social movements, the exponential rise in numbers attending the World Social Forum (WSF) meetings and the European Social Forum (ESF) meetings is chronicled by Donatella della Porta. The World Social Forum numbers rose from 20,000 participants in 2001 in Porto Allegre to attracting 155,000 registered participants in 2005. ${ }^{4}$ Della Porta argues that the fundamental driving force behind the social movements is a call to "reduce inequalities produced by the market and search for a new democracy." The ESF has specifically targeted the neoliberal policies on which the international trading system has been based and which has led to the adoption of Fair Trade principles and the popularity of that movement. The Declaration of the Assembly of the Movements of the 4th European Social Forum, held in Athens on May 7, 2006 read:

\begin{abstract}
Although the $\mathrm{EU}$ is one of the richest areas of the world, tens of millions of people are living in poverty, either because of mass unemployment or the casualisation of labour. The policies of the EU based on the unending expansion of competition within and outside Europe constitute an attack on employment, workers rights, public services, education, the health system and so on. The EU is planning the reduction of worker's wages and employment benefits as well as the generalization of casualisation. We reject this neoliberal Europe ... we are fighting for another Europe, a feminist, ecological, open Europe, a Europe of peace, social justice, sustain-
\end{abstract}

3. Alex Nicholls \& Charlotte Opal, Fair Trade: Market-Driven Ethical Consumption 39-40 (2005).

4. Donatella della Porta, The Emergence of European Movements? Civil Society and the EU 4 (June 30, 2007) (unpublished paper circulated at the European University Institute seminar "Governance, Civil Society and Social Movements," available at http://eui.eu/LAW/Events/CJIII4.pdf).

5. Id. at 6 . 
able life, food sovereignty and solidarity, respecting minorities' rights and the self-determination of peoples. ${ }^{6}$

One particular target of the ESF has been the European Partnership Agreements (EPAs) negotiated between ex-colonial countries and the European Union to end preferences on commodities such as sugar and bananas. This was a particular focus of the European Social Forum held in London in October 2004, when Traidcraft $^{7}$ led a campaign against EPAs. ${ }^{8}$ Fair trade is likely to play a vital role in mitigating the probable effect of the EPAs, particularly on the banana trade in the Caribbean. The Fair Trade movement has succeeded in initiating a Fair Trade Working Group within the European Parliament to "work towards the involvement of Fair Trade demands into relevant political processes such as the EU sugar reform and the revision of the Generalized system of Preferences." These preferences required revision following the "banana wars"10 and will be replaced by EPAs.

\section{Social Movements, Democracy and Fair Trade}

Research among participants of social movements showed a wide level of distrust of representative democracy and "[a]mong other actors and institutions, we might notice a strongly declining trust in the church and mass media, as well as in the unions in general and a stable (low) trust in the judiciary and (even lower) in political parties. Activists continue to trust instead social movements (and less, NGOs) as actors of a democracy from below."'

One of the tenets of the movements ${ }^{12}$ is that transnational companies are (if not running the world) at least centers of unchecked power with no democratic control

6. Id. at 10 (citing the Declaration of the Assembly of the Movements of the 4th European Social Forum, held in Athens on May 7,2006 addressing the EU).

7. Traidcraft is a specifically Christian-based movement aiming to lift poor farmers out of poverty by creating long-term trading relationships. It also campaigns to raise awareness of poverty.

8. E-mail from Anja Osterhaus, Advocacy Co-ordinator, Fair Trade Advocacy (Aug. 7, 2007) (on file with author).

9. Id.

10. See generally Banana Wars: Power, Production and History in the Americas (Steve Striffler \& Mark Moberg eds., 2003).

11. della Porta, supra note 4 , at 11 .

12. Joshua Karliner \& Ted Lewis, World Social Forum Conference on Transnational Corporations (Feb. 1, 2002), http://www.corpwatch.org/article.php?id=1728. 
over them, a sentiment which has been explored in my earlier work. ${ }^{13}$ The point explored in the Economist article and considered further here is whether the Fair Trade and Ethical Trading movements can influence trading policies and more specifically, whether that influence is democratic in nature. There is no doubt that consumers can exert influence on company behavior, ${ }^{14}$ although that influence will always be limited by factors over which they have little control. These factors include the fact that they must rely on the company providing vital information, which will not be forthcoming if it is likely to adversely affect the company's duty to the shareholders to "profit maximize." Nevertheless many companies have recognized that the ethical shopper is a valuable target and have consequently stocked goods carrying a wide range of certification marks which they are able to retail at a premium price. To what extent this is likely to have a lasting impact on behavior of companies towards stakeholders other than shareholders or corporate social responsibility generally is currently the subject of the Arts and Humanities Research Council (AHRC) funded research at Queen Mary College. ${ }^{15}$ The ethical trading movements have the potential to assist in democratization and the debate should concentrate on the extent to which they should be recognized as part of mainstream political thinking and legitimized by affording them a role in political decision making.

\section{What is Democracy?}

Many contend that for a variety of reasons democracy cannot simply mean churning out almost identical politicians every few years. ${ }^{16}$ The ability of such politicians to represent a wide range of possibilities has been severely eroded by a number of factors, some stemming from the "willing capture" of the state, ${ }^{17}$ others from glo-

13. See generally Janet Dine, Companies, International Trade and Human Rights (2005) (examining the effects of globalization on the relationships between human rights, property rights, and capitalist economies); Janet Dine, The Governance of Corporate Groups (2000) (discussing how "groups of companies operating on a global basis and out of regulatory control" have all but taken over the world).

14. See Purnima Bose, From Agitation to Institutionalization: The Anti-Sweatshop Movement in the New Millennium, 15 Ind. J. Global Legal Stud. 213 (2008).

15. See generally QMUL-Fair Trade Project, http://www.qmul-fairtradeproject.org (last visited Jan. 13, 2008).

16. See, e.g., Gunther Teubner, Societal Constitutionalism: Alternatives to State-centred Constitutional Theory, in Transnational Governance and Constitutionalism 3 (Christian Joerges et al. eds., 2004) (arguing that merely elevating actors such as MNEs into traditional governance is flawed because the designers "cannot free themselves of the fascination of nation-state architecture").

17. Dine, Companies, International Trade and Human Rights, supra note 13, at 27-31. 
balization ${ }^{18}$ and the ability of multinational companies to evade and supersede state regulation..$^{19}$ These twin forces mean that the state is "on the side" of the multinationals and, if state authorities deviate from subservience to corporate interests, they are able to evade regulation ${ }^{20}$ or leave. One of the consequences of the overwhelming consensus about the "proper" economic path to success (which has loosely been labeled the "Washington Consensus") is the "dumbing down" of politics to a narrow centrist band which is obsequious to "the market" and consequently to large market players, most notably transnational corporations. ${ }^{21}$ This has led not only to the "market state" ${ }^{22}$ but also to the fragmentation of power away from the traditional monolithic state structures. Additionally, it has led to the blurring of the boundaries between public and private realms, including public and private law. ${ }^{23}$ Regional and international agreements have also achieved fragmentation. ${ }^{24}$ This has made governance structures more complex and less responsive to democratic pressures. Power has become multicentric rather than monolithic, ${ }^{25}$ a transformation that has significant consequences for democracy. José Saramango says:

18. See Christiana Ochoa, The Relationship of Participatory Democracy to Participatory Lawmaking, 15 Ind. J. Global Legal Stud. 5 (2008).

19. It is well known that transnational companies are able to avoid state regulation by shifting resources between members of the group and exploiting their power over developing countries. See David C. Korten, When Corporations Rule the World (1995); Dine, The Governance of Corporate Groups, supra note 13.

20. One example of this is the extensive use of offshore tax havens. See Peter Alldridge \& Ann Mumford, Tax Evasion and the Proceeds of Crime Act 2002, 25 Legal Stud. 353, 360-62 (2005).

21. For a definition see United Nations Economic and Social Council, Work on the Formulation of the United Nations Code of Conduct on Transnational Corporations-Outstanding Issues in the Draft Code of Conduct on Transnational Corporations (E/C10/1985/5/2, May 22, 1985) and discussion in Janet Dine, The Governance of Corporate Groups, supra note 13, at 41-42.

22. Mary Ridell, Bishops Can't Bring Peace on Earth, The Observer, Dec. 29, 2002 (discussing Rowan Williams' views on the market state); Marie Sansom, The New Leader of the Opposition?, Guardian.co.uk, Feb. 27, 2009, available at http://www.guardian.co.uk/politics/2003/feb/27/past. comment.

23. Teubner argues that private law has become simply "juridification of economic action." Gunther Teubner, The Private/Public Dichotomy: After the Critique? (Jan. 18, 2007), http://www .re-public.gr/en/:p $=99$.

24. See Nick Bernard, Multilevel Governance in the European Union 15-17 (2000); Christian Joerges, Integration Through De-legalisation? An Irritated Heckler at 6-8 (European Governance Papers No. N-07-03, Iain F. Fraser trans., EUROGOV 2007), available at http://www .connex-network.org/eurogov/pdf/egp-newgov-N-07-03.pdf.

25. See generally Jan Aarte Scholte, Globalization and Governance: From Statism to Polycentrism (Centre for the Study of Globalisation and Regionalisation, Working Paper No. 130/04, 2004) (arguing that "contemporary large-scale and accelerated growth of transworld connectivity has rendered the statist mode of governance unviable and encouraged the emergence of polycentric 
The world today behaves like a madhouse. The worst of it is that the values we had more or less defined, taught, learned, are thought of as archaic as well as ridiculous. Respect for the world: who is that important to? The human being should be the absolute priority. And it isn't. It's becoming less and less so. It seems that it's more important to reach Mars than prevent 13 million Africans dying of hunger. Why would I want to know if there's water on Mars if we're polluting the water here on Earth, doing nothing to avoid it? Priorities need to be redefined, but there's no chance of redefining those priorities if we didn't confront the need to know what democracy is. We live in a very peculiar world. Democracy isn't discussed, as if democracy had taken God's place, who is also not discussed. ${ }^{26}$

Perhaps the discussion should begin with the understanding that markets are not all-powerful. "Adam Smith's invisible hand-the idea that free markets lead to efficiency as if guided by unseen forces-is invisible, at least in part, because it is not there." 27

Despite Saramango's despairing cry, there has always been intense debate about what a democracy actually consists of and connecting the diverse threads of democracy and the social and Fair Trade movements presents a formidable task. I have chosen to try to cut through the complexities by adopting a novel approach to the democracy question put forward by Charles Tilly. Tilly rejects the argument that it is possible to identify a "borderline" between democracy and non-democracy ${ }^{28}$ by an assessment of chosen factors such as those identified by Freedom House..$^{29}$ Instead, Tilly focuses his definition on state-citizen relations and argues that democracy is always in a state of dynamic movement with constant pressures toward democratization and de-democratization. ${ }^{30}$ "Democratization means net movement towards broader, more equal, more protected, and more binding con-

(multisited and networked) regulation"), available at http://www2.warwick.ac.uk/fac/soc/csgr/ research/workingpapers/2004/wp13004.pdf.

26. Julie Evans, The Militant Magician, The Guardian, Dec. 28, 2002, at 12 (quoting José Saramago), available at http://books.guardian.co.uk/departments/generalfiction/story/0,865566,00.html.

27. Joseph Stiglitz, There Is No Invisible Hand, The Guardian, Dec. 20, 2002, at 17, available at http://www.guardian.co.uk/comment/story/0,3604,863426,00.html.

28. Charles Tilly, Democracy ix (2007).

29. See Freedom House, http://www.freedomhouse.org/template.cfm ?page=351\&ana_page $=333 \&$ year $=2007$; TilLy, supra note 28 , at $2-3$.

30. TILLy, supra note 28. 
sultation. De-democratization, obviously, then means net movement towards narrower, more unequal, less protected, and less binding consultation. ${ }^{31}$ In seeking to uncover the causes of movement in either direction, he argues that there is a crucial difference between capacity of states and the health of their democracy. Here, capacity relates to a state's ability to implement its policies. "State capacity means the extent to which interventions of state agents in existing non-state resources, activities, and interpersonal connections alter existing distributions of those resources, activities and interpersonal connections as well as relations among those distributions. ${ }^{32}$ Democratization depends on a complex interaction between the democracy in the sense of broader, more equal, more protected, and more binding consultation and capacity to deliver. Tilly's central tenet is that democracy cannot be measured in the traditional ways which employ idealist, structuralist, or instrumentalist approaches. ${ }^{33}$ These he explains as:

[D]emocracy as an idea that someone (the Greeks? ${ }^{34}$ ) invented, starting a centuries-long effort to implement the idea. We might take the opposite tack, arguing that only the conditions of industrial capitalism could support broad, equal, protective, and mutually binding political relations between states and citizens. We might also think that competing models of government, once familiar to national elites, attracted different sorts of ruling classes, and that some of those chose dictatorship and others democracy. ${ }^{35}$

Tilly argues that attention should be paid to processes in order to identify the movement toward or away from democracy. The processes he identifies are "increasing integration of trust networks into public politics, increasing insulation of public politics from categorical inequality and decreasing autonomy of major power centres from public politics. ${ }^{36}$ The first process is encapsulated by the following:

[o]f breadth, equality, mutually binding consultation and protection, integration of trust networks into public politics most directly affects

31. Id. at 14 .

32. Id. at 16 .

33. Id. at 50 .

34. Id. at 26 (pointing out that the breadth of participation is extremely suspect due to the fact that the Greeks were slave owners and excluded women from politics).

35. Id. at 49.

36. Id. at 23 . 
mutually binding consultation. To the extent that people integrate their trust networks into public politics, they come to rely on governmental performance for maintenance of those networks. They also gain power, individual and collective, through the connections to government that those networks mediate. They acquire an unbreakable interest in governmental performance. The political stakes matter. Paying taxes, buying governmental securities, yielding private information to officials, depending on government for benefits, and releasing network members for military service cement that interest and promote active bargaining over the terms of its fulfilment. ${ }^{37}$

Trust networks "contain ramified interpersonal connections, consisting mainly of strong ties, within which people set valued, consequential, long-term resources and enterprises at risk to the malfeasance, mistakes, or failures of others." ${ }^{\text {38 }}$

This could serve as a precise definition for both social movements as well as the Fair Trade movement (and other ethical trading movements). As della Porta found, the social movements were trusted to act democratically whereas participants had extreme skepticism about trusting traditional political levers and institutions. ${ }^{39}$ The Fair Trade movement argues that "somewhere between the anti-globalisation protesters in Seattle and theories in economics textbooks lies a truly sustainable model for a trading system in which everyone benefits. Fair Trade represents such a model." ${ }^{30}$ If this claim is justified, the Fair Trade movement represents a concrete model for the social movements to campaign for, and the championship of the movement by the WSF and ESF and the foundation of a working group in the European Parliament shows that this is already underway. We need to test the model and then discuss whether democratization would be assisted by absorbing some of the lessons of fair trade at the national, regional, and international levels; in other words, by integrating the trust networks represented by the social movements, and in particular the ethical trading movements, further into decision making. Before proceeding to do so, two other processes considered by Tilly must first be examined.

37. Id. at 95 .

38. Id. at 81 .

39. Especially voting mechanisms and including the formation of political parties.

40. Nicholls \& Opal, supra note 3 , at 19. 


\section{The Role of INeQuality}

The second process identified by Tilly as an indicator of democratization is equality. Tilly argues that democracy works better if the political process has mechanisms which mitigate inequalities that are found in society. Where this does not occur, that democracy is threatened. ${ }^{41}$ Thus the argument is not that democracy cannot exist where there are significant inequalities, but that these inequalities must not appear in the political arena. By categorical inequalities Tilly means "organized differences in advantages by gender, race, nationality, ethnicity, religion, community and similar categories." ${ }^{22}$ "Increasing categorical inequality threatens democracy because it gives members of advantaged categories means and incentives to:

- Opt out of democratic bargains

- Create beneficial relations with state agents

- Shield themselves from onerous political obligations

- Use their state access to extract more advantages from unequal relations with non-state actors

- Use their influence over the state for further exploitation or exclusion of subordinate categories, and thus

- Move their regimes even further away from broad, equal, protected, mutually binding consultation. ${ }^{2 * 3}$

Thus, this proposition argues that it is possible to have significant inequality and rely on political magic tricks to isolate political decision making from that inequality by mechanisms which do not reflect those inequalities in a formal arena. This is only true to a very limited extent. Those who are starving do not vote and even marginalization can breed despair at having any influence. ${ }^{44}$

\section{The Democratic Importance of All Forms of Equality}

Both Barbara Ehrenreich and Polly Toynbee vividly portray the "invisibility" factor as part of the experience of poverty due to low pay in the United States and

41. TiLLy, supra note 28 , at 111.

42. Id. (citations omitted).

43. Id.

44. See Dine, Companies, International Trade and Human Rights, supra note 13 , at 5. 
United Kingdom respectively. ${ }^{45}$ James Fallows notes the lack of shared spaces and services. In the United States

as public schools and other public services deteriorate, those who can afford to do so send their children to private schools and spend their off-hours in private spaces - health clubs, for example, instead of the local park. They don't ride on public buses and subways. They withdraw from mixed neighbourhoods into distant suburbs, gated communities or guarded apartment towers; they shop in stores that, in line with prevailing 'market segmentation' are designed to appeal to the affluent alone. ${ }^{46}$

Toynbee writes,

London was a sadder, duller, more impoverished place.... Wherever I walked, everything I passed was out of bounds, things belonging to other people but not to me.... This is what 'exclusion' means, if you have ever wondered at this modern wider definition of poverty. It is a large No Entry sign on every ordinary pleasure. ${ }^{47}$

This polarization of society is neatly summed up in Naomi Klein's metaphor of Fences and Windows to describe the separation of the haves and have-nots (Fences) and the opportunities for hope (Windows). ${ }^{48}$

Such exclusion does not readily lead to political participation. Tilly apparently discounts the effects of the way in which inequality and discrimination are built into political systems in an institutional way, an issue discussed below in relation to institutional racism and corruption. Further, the third process identified by Tilly is the antithesis to the inequality issue.

45. See generally Barbara Ehrenreich, Nickel and Dimed: On (Not) Getting by in America (2001); Polly Toynbee, Hard Work: Life in Low-Pay Britain (2003).

46. Ehrenreich, supra note 45, at 217.

47. Toynbee, supra note 45, at 239.

48. Naomi Klein, Fences and Windows: Dispatches from the Front Lines of the Globalization Debate xviii-xxvii (Debra Ann Levy ed., 2002). Klein argues that global society has created many fences; "barriers separating people from previously public resources" both physical barriers and virtual ones such as education being restricted by the charging of fees. Windows are signs of hope of breaking down barriers such as the World Social forum and reclaiming public spaces. 


\section{Decreasing the Autonomy of Power Centers}

The third process identified by Tilly as an indicator of democratization is decreasing the autonomy of major power centers from public politics. A revealing part of the discussion of this issue comes when Tilly deals with the de-democratization of Russia by President Putin: "Yet in one regard Putin may surprisingly have been promoting longer-term changes that will eventually facilitate Russian democratization. Although he was permitting Russian military dangerously broad autonomy in the Caucasus, he was also subordinating capitalists who had acquired extraordinary independence from state control. ${ }^{49}$ Here Tilly makes a good point but misses another. The control of corporate power by state authorities is a step in favor of democratization; however, in most of the world state control is illusory. In this respect, Tilly fails to ack nowledge this point and appears to be operating in a pre-transnational corporate world. Corporations not only Rule the World ${ }^{50}$ but they also have bought the politicians, if not with money then with economic argument and sheer economic power. The result of this is to corrupt the whole system. Since democratic governments have come to believe that what benefits corporations also benefits their citizens, governments perceive themselves as existing to encourage corporations in whatever it takes to increase profits. So democratization by decreasing the autonomous power of corporations can only come by accepting that an alternative approach to the economic system which decreases the reach of corporate power and its elites is required. This can only be achieved by popular pressure and raises very difficult questions about the extent to which social and ethical trade networks should integrate with current political systems.

It is therefore arguable that the United States, United Kingdom, and Europe have significantly de-democratized in recent years due to the failure to integrate the social movements as significant trust networks, because of the increase in inequality, and because of the "willing capture" by companies of the "market state" giving significant autonomous power to corporations. Can the ethical trading movements, and in particular the Fair Trade movement, make a difference to this trajectory?

\section{Ethical Trading v. Corporate Structures}

As mentioned above, the Economist recently posed the following non-question in an attack on the Fair Trade movement: "Has the supermarket trolley dethroned

49. Tilly, supra note 28 , at 137.

50. See Korten, supra note 19, at 12; John Pilger, The New Rulers of the World 2 (2002). 
the ballot box? "' The thesis of the piece was that ethical choices were next to impossible and that conventional politics supplies the only route to world salvation. In a further attack, Max Hastings accused Fair Trade and organic movements of peddling "quack remedies" and indulging "the almost unlimited gullibility of wellmeaning consumers." ${ }^{\prime 2}$ However, as Ian Bretman pointed out, ethical shopping, however imperfect, brings the wishes of consumers to the attention of politicians and puts fairness on to the political agenda:

Most people ask, in the face of the apparent inertia of our political systems, 'what can I do?' This is not instead of government action but in addition to it. Their efforts deserve more than cheap sneers. Instead of Scrooge's refrain of 'bah, humbug,' wouldn't a cheer for the goodwill shown by the world's ethical shoppers be more appropriate ${ }^{53}$

There are indeed difficult philosophical issues surrounding ethical shopping. To adequately examine these issues, more than a few newspaper sound bites must be scrutinized..$^{54}$ This paper explores the complex relationship between trade relationships built on a traditional basis and the poverty these are said to cause, to discover whether the claim of the movement to be a pattern for a possible replacement economic system has validity and therefore whether it is time for decision makers to acknowledge that social and ethical networks should be integrated into or should drive decision making in order to promote democratization.

The growth of ethical "brands" is driving more and more companies to claim the moral high ground in order to attract the "ethical dollar." ${ }^{55}$ This attitude appears at first sight to be in sharp contrast to the way in which corporate governance rhetoric has previously built on the legal underpinnings of corporate design to create companies allegedly with the sole aim of maximizing economic returns to share-

51. Voting with Your Trolley, supra note 2.

52. Max Hastings, We May Yearn to Be Green, but We Can't Afford to Be Gullible, The GuardIAN, Dec. 11, 2006, available at http://www.guardian.co.uk/print/0,329658924-103677,00.html.

53. Ian Bretman, We Shouldn't Sneer at the Goodwill of Ethical Shoppers, The Gundian, Dec. 13, 2006, available at http://www.guardian.co.uk/print/0,329660923-103677,00.html.

54. These issues are being explored by a team of researchers under the auspices of a grant from AHRC. The ethical shopping issue is being explored principally by Dr. Andrew Fagan. See Andrew Fagan, Buying Right: Consuming Ethically and Human Rights, in Human Rights and Capitalism: A Multimisciplinary Perspective on Globalisation 115 (Janet Dine \& Andrew Fagan eds., 2006).

55. Money which consumers are willing to spend if the product is believed to have some ethical property, often over and above the usual market price of a particular commodity. 
holders. ${ }^{56}$ However, one significant question is whether or not companies are using the ethical trading regime not to alleviate poverty or as a revolutionary new way of trading but in accordance with their perceived goal of profit maximization. This question has become much more important following the "mainstreaming" of the Fair Trade movement. This saw fair trade products no longer traded exclusively by Oxfam and other Alternative Trading Organisations but also available in mainstream retailers such as the big supermarkets. Many of these are multinational companies with aggressive marketing strategies. If the Fair Trade and ethical trading movements are comfortable with the concept of profit maximization then it is arguable that they cannot be a pattern for an alternative trading system and they may therefore have little to contribute to democratization.

However, it must not be forgotten that companies are simply a product of human design. Companies are designed by societies and their profits underpin much of our wealth. So when they strike bargains with evil regimes, repatriate their profits, and sell us goods produced at low prices because of sweated or slave labor or take excessive margins when retailing "ethical" goods, it is not because of the inherent evil of the people that work in corporations but as a direct result of the legal design of corporations and the operation of the international legal system. ${ }^{57}$ The U.S./U.K. model of companies has shareholders as the primary focus- the company must serve the interests of shareholders and directors are appointed and dismissed by shareholders. Nevertheless, directors are to act in the interest of the company and usually owe no direct duties to shareholders. Since this structure does not necessarily equate shareholders with the company, the company could be construed as involving the interests of others. Additionally, the structure does not equate shareholder interests with "profit maximization" and impose a duty on directors to achieve such a goal. It would be interesting to trace the history of the assumption that shareholder interests and profit maximization are coterminous, no company law that I have ever seen makes this assumption. Nevertheless, recent discourse has imposed the concept of profit maximization on the assumption that this is what shareholders require and adopted the second assumption that shareholders and the

56. Profit maximization is not a legal term and has been constructed as an "expansionary property claim" by reference to alleged shareholder ownership of companies. See Dine, Companies, International Trade and Human Rights, supra note 13, at 263.

57. There is no international regulation of transnational corporations. For the opportunities provided by the international legal system see Dine, Companies, International Trade and Human Rights, supra note 13, at 97-166. 
company are one and the same thing. ${ }^{58}$ Such an understanding of corporate aims has wide implications for corporate behavior since all considerations, other than profit, are seen as "negative externalities" to be adhered to in a minimalist way or bargained away if possible. It has also been one of the underlying causes of spectacular bankruptcies such as Enron and Worldcom. ${ }^{59}$ Much of this focus has been informed by the fiction that companies are "owned" by shareholders and the consequent "strong" claim that shareholders have to protection of their "property rights." We design companies according to this understanding. ${ }^{60} \mathrm{It}$ is arguable that these concepts are a "corruption" of a proper understanding of the role of corporations in society and that the Fair Trade movement might inform a less corrupt understanding of corporations serving the common good.

\section{A. Corrupt Companies?}

Carol MacLennan argues that the current behavior of companies represents a form of institutionalized corruption, surely another indicator of de-democratization:

Market values, which have their root in a pre-industrial, liberal society based upon democratic citizenship and agrarian, small business enterprises, have morphed into a new ethic of corporate capitalism which no longer resembles the business culture of the past. ... Corporate behavior in the US has become increasingly 'corrupt' and the behavior of officials in the Enrons and Worldcoms is not isolated.... it is pervasive and institutionalised. That means, it is more than criminal behavior by a few bad actors in an otherwise clean enterprise. It is institutionalized in the everyday world-view and processes of corporate action. ${ }^{61}$

MacLennan's study is principally into the close networks which link the po-

58. That is that the company exists solely for the benefit of shareholders and/or that the company is "owned" by the shareholders. See Paddy Ireland, Company Law and the Myth of Shareholder Ownership, 62 Mod. L. Rev. 32 (1999); Paddy Ireland, Property and Contract in Contemporary Corporate Theory, 23 Legal Stud. 453 (2003).

59. See Bethany Mclean \& Peter Elkind, The Smartest Guys in the Room; The Amazing Rise and Scandalous Fall of Enron (2003); Janet Dine, The Capture of Corruption, 20 Pac. McGeorge Global Bus. \& Dev. L. J. 1 (2006).

60. Janet Dine, Using Companies to Oppress the Poor, in Human Rights and Capitalism, supra note 54 , at $48,50-51$.

61. Carol MacLennan, Corruption in Corporate America: Enron-Before and After, in Corruption: Anthological Perspectives 158 (Dieter Haller \& Cris Shore eds., 2005) [hereinafter Corruption]. 
litical and economic elites. However, she also notes that "Definitions of morality, public interest and personal responsibility in corporate board rooms and executive offices may in fact be quite different from those of the rest of the middle, working and poor classes." ${ }^{2}$ An interesting example of this is Jeffrey Skilling's (former CEO of Enron) belief that he is entirely innocent of wrongdoing. ${ }^{63}$ This is unlikely to be mere denial and may well stem from an unholy mixture of the "alpha male entitlement" syndrome, which leads powerful people (not always males) to deny that the rules of ordinary life apply to them. MacLennan insists that:

[C]orruption implies something systematic, institutionalised and perhaps endemic to an organisation or culture. It is pervasive, infused or embedded in the system. ... Corrupt or criminal behaviour is individual. If an alleged crime occurs, individuals are held responsible and receive punishment through the courts. But corruption is institutional, patterned-perhaps criminal and unethical from outside, but not necessarily perceived as such by insiders. All of the attention to the individual criminal executive is a detour from figuring out how corruption works. An example is the coverage of the prosecution of Enron's executives, Chief Executive Officer Jeffery Skilling and Chief Financial Officer Andrew Fastow. All eyes are on the courtroom ... and on possible jail sentencesthus isolating the executive as the criminal. The corporate culture that bred corruption, and the social expectations of the elite that ruled the organisation, have escaped scrutiny. ${ }^{64}$

Can this model of corporations and consequent profit maximization behavior survive any significant onset of ethical consumerism? Or will the profit motive simply capture the ethical market and exploit it for its own ends? Will companies have to adopt some form of corporate social responsibility in order to attract customers and avoid boycotts? Would the adoption of ethical trading concepts assist democratization?

62. Id. at 163 .

63. Profile: Jeffrey Skilling, BBC News, Oct. 23, 2006, available at http://news.bbc.co.uk/2/hi/ business/6077062.stm.

64. MacLennan, supra note 61 , at 164-65. 


\section{B. Fair Trade and Free Trade}

In order to make a case for the importance of protecting and supporting the Fair Trade movement it is necessary to show why the international trading regime is unethical, thus prompting an "ethical alternative." In Companies, International Trade and Human Rights ${ }^{65} \mathrm{I}$ argue that this is indeed the case and that the system has been designed by governments who are in "willing capture" to the interests of the big corporations whose interests they see as aligned with those of the home state of the giant corporations. Here I will argue further that the design of the international trading regime amounts to institutional corruption and does, indeed, require a strong ethical response.

\section{The Institutional Corruption of the International Trading Regime}

Recently, we have heard a great deal about the evils of corruption, to the extent that "corruption is often discussed in the kinds of language and symbolism reserved for life-threatening diseases." ruption as the single greatest obstacle to economic and social development." ${ }^{\text {"6 }}$ Steven Samson notes: "In the last five or six years, anti-corruption practices have diffused transnationally and have become organized globally. We have seen the emergence of a world of anti-corruption with its own actors, strategies, resources and practices, with its heroes, victims and villains." ${ }^{18}$ Samson moots two possible explanations for this powerful recent emergence of the anti-corruption movement. First, he argues, "The fight against corruption is virtuous, and those who form part of the anti-corruption community' are thus 'integrity warriors." ${ }^{\text {"’ }}$ However, definitions of corruption vary. One definition of corruption was put forward by Edward Banfield in 1975. He described corruption as a relationship between three parties: the public as principal, the public official as agent obligated to fulfill the wishes of the principal, and a third party seeking to have the agent work on their behalf instead. ${ }^{70}$ Many

65. See generally Dine, Companies, International Trade and Human Rights, supra note 13.

66. Michael Johnston, Syndromes of Corruption (2005).

67. World Bank, A Guide to the World Bank 143 (2007).

68. Steven Samson, Integrity Warriors: Global Morality and the Anti-Corruption Movement in the Balkans, in Corruption, supra note 61, at 103, 106.

69. Id.

70. See Edward C. Banfield, Corruption as a Feature of Governmental Organizations, 18 J.L. \& Econ. 587, 587 (1975). 
would accept that this is a perfect description of the international trade regime with trade representatives who should fulfill the wishes of the people instead of acting against their interests and favoring multinational corporations. ${ }^{71}$ However, this ignores the fact that corporations have been designed and structured by society and that the rich reap the benefits of their operations. In other words, it ignores the polarization of the world into those who benefit from transnational corporations (TNC) activity and those who suffer. It relies on a state-centric view of the world which would consider that acting for the public within a particular state would fulfill the duty of the official. In fact that also oversimplifics the issuc as well, since even in the richest nations the increasing inequality partially caused by TNC activity means that the activities of trade representatives in promoting the power and wealth of TNCs could be seen as corrupt by one part of the "public." For example, the agency or call-center workers, cleaners, and caterers, ${ }^{72}$ while another part of the public, comfortably endowed with pensions and savings, might, when considering only their self-interest, consider their work to be beneficial.

While the system may be arguably corrupt, using the Edward Banfield definition, some have argued that a wider understanding of corruption should be adopted. John Kleinig and William Heffernan reject the Banfield definition of corruption:

It is not the predominant understanding of the term in the Oxford English Dictionary; it leaves out much of what has historically been deemed corrupt; and it relies on the superficial clarity of a private/ public distinction and an unexamined view of what counts as improper use. Corruption is not the exclusive failing of public officers; there may also be personal corruption, corrupt institutions, and corrupt cultures. ${ }^{73}$

Arnold Heidenheimer distinguishes between black, white, and gray corruption. Black corruption was perceived by both elites and ordinary people as fundamentally detrimental to society, white acts were seen by both groups as of some benefit to society, and gray corruption was viewed differently by elites and ordinary people. ${ }^{74}$

71. See Dine, Companies, International Trade and Human Rights, supra note 13 (especially bibliography).

72. See generally sources cited supra note 45 .

73. John Kleinig \& William C. Heffernan, The Corruptibility of Corruption, in Private and Public Corruption 3, 3 (William C. Heffernan \& John Kleinig eds., 2004).

74. Arnold J. Heidenheimer, Introduction to Political Corruption: Readings in Comparative Analysis 3, 26-27 (Arnold J. Heidenheimer ed., 1970). 
This paper argues that, while the international trading system is arguably corrupt under the classic Banfield definition, it is most certainly a form of institutional corruption. This concept follows the McPherson understanding of institutional racism which found that some institutions are captives of historic prejudice so that the way in which they operate inevitably disadvantages some sector of society. ${ }^{75}$ In response to the murder of a black headmaster, Stephen Lawrence and the subsequent bungled police investigation, the McPherson report found that the police force was infected with institutional racism. Citing Dr. Benjamin Bowling, the report agreed that

institutional racism is the process by which people from ethnic minorities are systematically discriminated against by a wide range of public and private bodies. If the result or outcome of established laws, customs or practice is racially discriminatory then institutional racism can be said to have occurred. Although racism is rooted in widely shared attitudes, values and beliefs, discrimination can occur irrespective of the intent of the individuals who carry out the activity of the institution. ${ }^{76}$

The report went on to adopt the following definition of institutional racism:

The collective failure of an organization to provide ... an appropriate and professional service to people because of their colour, culture or ethnic origin. It can be seen or detected in processes, attitudes and behaviour which amount to discrimination through unwitting prejudice, ignorance, thoughtlessness and racist stereotyping which disadvantage minority ethnic people. ${ }^{77}$

Now it is indeed arguable that the way in which the international trade system has been constructed is racist. ${ }^{78}$ However, the point made here is that it is also institutionally corrupt. That is, the prejudices of the powerful have caused them to craft laws which systematically discriminate against the poorest people on earth and that

75. Home Department, The Stephen Lawrence Inquiry (Feb. 1999), Cm. 4262-1, at 6, available at http://www.archive.official-documents.co.uk/document $/ \mathrm{cm} 42 / 4262 / 4262$.htm.

76. Id. at 6.33 .

77. Id. at 6.4 .

78. See Fernne Brennan, Time for a Change: Reforming WTO Rules to Take Account of Reparations, in Human Rights and Capitalism, supra note 54, at 254. 
this comes within a number of definitions of corruption..$^{79}$ In the case of the international trading system, the design is a result of "capture" by incoherent economic dogmas which do not take account of reality. Thus, the design of the International trading system is itself a form of corruption which has been systematically defrauding the majority of the public for many years via public officials who have put in place a pernicious trading system which favors the wealthy minority over the poor majority. While clearly this cannot be "black" corruption in Heidenheimer's terms, since there is a fundamental divide between elites and the majority of ordinary public, the "Global crisis" I described in Companies, International Trade and Human Right ${ }^{80}$ has been designed for us by elite public officials, themselves captured by economic dogma and thus comes squarely within the concept of institutional corruption. It also comes squarely within yet another definition of corruption-J. Peter Euben argues from the basis of the Oxford English Dictionary which associates corruption with a cluster of words- - decay, degeneration, disintegration, and debasement.' ${ }^{\text {'1 }}$ Degeneration, disintegration, and debasement are clearly found as a result of the rules of international commercial law which have the following effects.

Using almost any statistics "we certainly know that the problem of world poverty is catastrophic." ${ }^{\text {"82 }}$ Of 6.133 billion human beings, in 2003-06:

- 799 million are undernourished, ${ }^{83}$

- 50,000 humans daily die of poverty related causes, ${ }^{84}$ and

- "the global poverty death toll over the 15 years since the end of the Cold War was around 270 million, roughly the population of the US." $" 85$

And the figures go on and on:

79. See J. Peter Euben, Pure Corruption, in Private and Public Corruption, supra note 73, at 53.

80. See Dine, Companies, International Trade and Human Rights, supra note 13, at 1.

81. Euben, supra note 79, at 55.

82. Thomas Pogge, The First Millennium Development Goal: A Cause for Celebration?, 5 J. Hum. DEv. 377, 385 (2004), available at www.etikk.no/globaljustice/oslo_Global_Justice_mainlecture.doc.

83. Human Development Report 2003: Millennium Development Goals: A Compact Among Nations to End Human Poverty 87-88 (Sakiko Fukuda-Parr et al. eds., 2003) (published for the United Nations Development Programme), available at http://hdr.undp.org/reports/ global/2003/.

84. Poverty-related causes include: starvation, pneumonia, tuberculosis, measles, malaria, and pregnancy-related causes. See World Health Report 2000: Mental Health: New Understanding, New Hope 46-49 (World Heath Organization 2001).

85. Pogge, supra note 82, at 386. 
- 34,000 children under 5 die daily from hunger and preventable diseases, ${ }^{86}$

- 1 billion lack access to safe drinking water. ${ }^{87}$

This is corruption on a grand scale by utilizing Rigged Rules and Double Standards ${ }^{88}$ precisely as defined in the Oxfam report which bears that title.

The consequences of this for democratization are clear. Tilly accepts that increases of categorical inequality are an important indicator of de-democratization so even on his terms the system is failing to democratize. I would argue further that institutional corruption in the system means that categorical inequalities are increasing because, far from being ameliorated by political processes, inequality is fostered and encouraged by them. This is de-democratization on a grand scale.

\section{The Methodology of Corruption: The Role of International Commercial Law and Market Mechanisms}

Before the recent extensive liberalization of the world economy, which has led to the opening of markets and the abolition of many protectionist measures, the way in which individual economies were run contained an element of planning and state control. With the emphasis on building an open world economy the control mechanisms operated by member states have been significantly reduced. ${ }^{89}$ This has many parallels with the opening of the markets of the Soviet Union and has similar social and legal consequences, including changing the role of commercial law. In this case, we are considering international commercial law, but there are significant parallels with domestic commercial law. The role of commercial law in any market economy, including a global market, is to allocate risk. Controlled economies attempted to eliminate the risks of commercial transactions to individuals, transferring the risk of failure to the whole community. The role of commercial law is simply to allocate

86. United States Department of Agriculture, U.S. Action Plan on Food Security: SoluTIONS To Hunger iii (1999), http://www.fas.usda.gov/icd/summit/usactplan.pdf.

87. Human Development Report 2003, supra note 83, at 103.

88. See generally Kevin Watkins \& Penny Fowler, Rigged Rules and Double Standards: Trade, Globalisation, and the Fight Against Poverty (2002) (discussing how the rules governing international trade are "rigged in favor of the rich"), available at http://www.oxfam.org.uk/ what_we_do/issues/trade/downloads/trade_report.pdf.

89. The member states of the World Trade Organization are constrained by the rules of that organization. See generally, The Political Economy of International Trade Law: Essays in Honor of Robert E. Hudec (Daniel L. M. Kennedy \& James D. Southwick eds., 2002) [hereinafter The Political Economy]. 
parts of the economy to different operators. One factory might be told to produce 2,000 tractors, another 5,000 cars. The price will be fixed by commercial law. No risk is undertaken by individuals. Economic failure is borne by the state. The move to a market economy from a controlled economy changes the role of commercial law by introducing the factor of individual risk. It thus entails complex political questions about which market participants shall bear the risk of market transactions.

A very simple example illustrates this fundamental role: the law of contract. At first sight, agreement between two individuals to buy and sell might seem a politically neutral transaction and the decision by the state to provide enforcement mechanisms to back such a transaction (such as sanctions for non-performance) might similarly appear to be politically uncontroversial. However, immediately when any disparity of bargaining power is taken into consideration, a state decision to provide enforcement mechanisms will clearly benefit the party who started in the more powerful position since that bargaining power will have been used to gain a more beneficial bargain. Only if safeguards such as unfair contract terms legislation are enacted to re-balance the equation can neutrality be regained. The same argument works in exactly the same way at an international level. An agreement between states with equal bargaining power may be considered to be politically neutral, but when they are of disparate power the "contract" is of profound political importance. In this respect, it is significant that the first quasi-judicial enforcement mechanisms at the international level have been designed and operate to enforce international commercial law and clearly favor richer nations with more diverse economies. ${ }^{90}$ It is noteworthy that none of the least developed nations have brought actions under the World Trade Organization Dispute Settlement Understanding and those which have featured complaints from developing countries are often initiated by TNCs. ${ }^{91}$ It would be impossible for developing nations to use the eventual sanction of trade retaliation against a powerful and diverse economy even if they were able to ignore political threats and prosecute the action in the first place. In this respect, the extreme pressure put on South Africa to alter laws put in place in 1997 to ensure a supply of cheaper generic drugs to AIDS sufferers, as opposed to patented drugs, which make huge profits for multinational pharmaceutical companies, is informative. South Africa is one of the more powerful developing nations, but came under

90. The sanction which may be imposed if a nation wins a case at the WTO is trade sanctions. It is very unlikely that, say Gambia, could damage the U.S. or EU economies by imposing sanctions. On the other hand a ban on peanut imports by either the European Union or United States would devastate the economy of Gambia, which relies heavily on peanut export.

91. See, e.g., Appellate Body Report, European Communities—Regime for the Importation, Sale, and Distribution of Bananas, WT/DS27/AB/R (Sept. 9, 1997). 
extreme political pressure to repeal the law although the public relations "own goal" of suing Nelson Mandela eventually paid off and the drug companies withdrew their case and paid the costs of the South African government. ${ }^{92}$

The design of international trade law bears an uncanny resemblance to the way in which the English colonized North America. "The English could congratulate themselves on the honorable way they were populating North America. They could see the Indians growing poorer but they did not conceive that they were the agents of the Indian's impoverishment. They were not taking the Indian's land by force of arms, after all. They were buying it on the open market." ${ }^{13}$

There were transactions called "treaties," but of course they were not genuine contracts, because the Indians did not consent to sell their land. Indians had different conceptions of property than the European settlers, so they could not have understood what the settlers meant by a sale. The Indians were really conquered by force, but Americans and their British colonial predecessors papered over their conquest with these documents ${ }^{94}$ to make the process look proper and legal..$^{95}$

One of the arguments put forward by proponents of the present system is that the World Trade Organization (WTO) is a democratic system and that all nations consented to the treaties which bind them. ${ }^{96}$ On the face of it the WTO has highly democratic decision making processes where one objection could prevent a decision being reached.

Moore argues that

the undemocratic claim is based upon a basic fallacy. The WTO is not imposed on countries. Countries choose to participate in an open, rules-based multilateral trading system for the simple reason that it is overwhelmingly in their interest to do so. The alternative is a less open, less prosperous, more uncertain world economy-an option few countries would willingly choose. It is difficult to con-

92. See Graham Dutfield, Intellectual Property, Biogenetic Resources, and Traditional K NOWLEDGE (2004).

93. Stuart Banner, How the Indians Lost Their Land: Law and Power on the Frontier 84 (2005).

94. In 1609, William Crashaw stated that "[a] Christian may take nothing from a Heathen against his will, but in faire and lawfull bargaine." William Crashaw, A Sermon Preached in London Before the Right Honourable the Lord Lawarre D3 (London, 1610).

95. BanNer, supra note 93 , at 1 .

96. Mike Moore, A World without Walls: Freedom, Development, Free Trade and Global Governance 103-04 (2003). 
ceive of a system that could be more democratic... The multilateral trading system works precisely because it is based on persuasion, not coercion-rules, not force. ${ }^{97}$

Further,

All decisions-from the creation of the GATT to 2001's launch of the Doha Development Agenda-have been taken collectively by the Member governments themselves in the numerous councils and committees, the most important of which is the Ministerial Meeting. Each WTO Member has equal rights and an equal vote under the agreements. Because no decision is taken unless all Member governments agree, effectively every country - from the largest to the smallest - has the power of veto. ${ }^{98}$

However, some scholars see the WTO differently and deny that the WTO treaties are any more consensual than the taking of Indian lands. "The outcome of the Uruguay round was tainted by threats. The U.S., in particular, frequently expressed (and demonstrated) its readiness to use 'Special 30l' against countries whose intellectual property regimes it judged to be weak. Such threats played a role in producing the strong TRIPS [Trade-Related Intellectual Property Rights] agreement." 99

The parallels with the conquest of the North American Indians are stark:

Any given decision on the part of Indians to sell land, like any decision made by anyone about any subject, may be more or less voluntary, along a continuum that lacks any dividing line between categories. There is a large middle ground between conquest and contract.... Every land transfer of any form included elements of law and elements of power.... the more powerful whites became relative to Indians, the more they were able to mould the legal system to produce

97. Id.

98. Id. at 105.

99. Brian Hindley, What Subjects Are Suitable for WTO Agreement?, in The Political EconoмY, supra note 89 , at $157,164$. 
outcomes in their favour-more sales, of larger tracts, at lower prices than would have existed had power relationships been more equal..$^{100}$

As a result of the artifice of "consent," the powerful are comforted:

the Anglo-Americans could sincerely believe, for most of American history, that they were not conquerors, because they believed they were buying land from the Indians in the same way they bought land from each other. What kind of conqueror takes such care to draft contracts to keep up the appearance that no conquest is taking place? A conqueror that genuinely does not think of itself as one. ${ }^{101}$

The WTO proponents similarly comfort themselves with the belief that the trading regime has been democratically and consensually constructed. The end result of both processes is injustice.

Perhaps worse than the pretense of consent, the commitment to free trade across the world is fundamentally violated by rich country protectionism of which a small example is U.S./EU protectionism which in agriculture alone subsidizes its own farmers to the tune of more than $\$ 20$ billion per annum ${ }^{102}$ and the system systematically works against impoverished countries. ${ }^{103}$

This also has resonance with the experience of the North American Indians. The English wrote, "After treaties are solemnly made, we fulfil, modify or abrogate them as suits our own convenience."104

Alex Nicholls and Charlotte Opal discuss the reasons why the economic theories on which the push to openness of markets has been based are flawed. The theory of benefits flowing from free markets engenders market failure when applied to poorer countries, especially those with geographical and historical limitations, the latter often the result of colonial exploitation..$^{105}$ The WTO system depends on the theory of comparative advantage developed following selected

100. BANNER, supra note 93 , at 3-4.

101. $1 d$. at 6 .

102. See generally Liz Stuart, Truth or Consequence: Why the EU and the US Must Reform Their Subsidies, or Pay the Price (Oxfam Briefing Paper No. 81, 2005) (discussing the multi-billion dollar trade subsidies of the EU and US), available at http://www.oxfam.org/en/files/bp81_truth_or _consequences/download.

103. See Watkins \& Fowler, supra note 88.

104. BANNER, supra note 93 , at 251.

105. See generally Nicholls \& Opal, supra note 3. 
doctrines from Adam Smith and David Ricardo. Nicholls and Opal offer a lucid and succinct description:

Under the theory of comparative advantage, countries export what they are relatively good at producing and they import what they cannot produce sufficiently. Mountainous Guatemala grows highquality cloud-forest-grown coffee. Japan manufactures technologically advanced electronic products. Opening up countries to international trade allows Japanese electronics producers to import delicious coffee, and Guatemalan coffee farmers to access high-tech products. Under free trade, both parties are better off: international trade is thus a win-win situation in which everyone benefits. Supporters of free trade insist that the unfettered movement of goods, services and finance between countries offers the most efficient model of transactional business. Inherent in this is the understanding that whilst some benefit, others will inevitably fail, but this still works ultimately for the general good, weeding out the weak and inefficient. ${ }^{106}$

The problem with this theory (apart from its environmental impact) is that the macroeconomic conditions on which it is based are absent, especially from rural agricultural societies, which were reduced to basic commodity trading as a result of colonization. ${ }^{.07}$ In particular, the following conditions on which the macroeconomic model is based are missing: ${ }^{108}$

- Easy market access

- Perfect information

- Access to financial markets

- Access to credit

- Ability to switch to other sources of income generation ${ }^{109}$

- Strong legal systems and enforcement of laws ${ }^{110}$

106. Id. at 17.

107. See Dine, Companies, International Trade and Human Rights, supra note 13, at 133-57.

108. See generally Joseph E. Stiglitz \& Andrew Charlton, Fair Trade for All: How Trade Can Promote Development (2005) (providing a more detailed analysis of this issue).

109. See also id. at 171-214 (discussing the adjustment costs created by trade liberalization).

110. Nicholls \& Opal, supra note 3, at 18-19 (supplying convincing arguments under all heads). 
Probably the most fundamental of the difficulties identified by Nicholls and Opal is the inability to switch to other sources of income generation. Nicholls and Opal argue,

This is clearly not the case for the world's poor. Even if isolated producers had access to price information, their ability to change their source of income is limited. The 1.2 billion people who live on less than $\$ 1$ a day are extremely risk-averse. Switching from growing a crop that your grandfather grew to a higher-priced crop that no one in your village has ever grown before is an extremely risky activity. For families with no slack in their income and little by way of savings, risk-taking is not an option. ${ }^{11}$

Producers of primary commodities are in a particularly vulnerable position, as are the countries which depend on primary commodities for their export earnings. ${ }^{112}$ John Keynes called for such commodities to be purchased "not at lowest price but a level sufficient to provide producers with proper nutritional and other standards." ${ }^{{ }^{13}}$ However, this philosophy has been lost in the drive to profit maximization and reliance on "market forces." 114 Abandoning such an approach brings us back to the concept of corruption, in particular the definition which associates corruption with a cluster of words- “ "decay, degeneration, disintegration, and debasement." 15

It is therefore the general liberalization under the WTO agreements and other trade agreements which may prevent the attainment of legitimate domestic human rights policy goals. International commercial law fails in a fair attribution of risk among peoples and would clearly fail the Rawlsian test of a policy designed from behind the veil. ${ }^{116}$

\section{Id. at 19.}

112. More than fifty developing countries depend on three or fewer commodities for over $20 \%$ of exports. Food and Agricultre Organization of the United Nations, Declining Commodity Export Earnings and Food Import Bills (2005), http://www.fao.org/newsroom/en/focus/2005/89746/ article_8975len.html.

113. John Keynes, The International Control of Raw Commodity Prices, in THE Collected WRITings of John Maynard Keynes, Vol 27167 (E. Johnson \& D. Moggridge eds., 1946).

114. Dine, Companies, International Trade and Human Rights, supra note 13, at 41-96.

115. Euben, supra note 79, at 55.

116. For a detailed description of Rawls' theory, see generally John Rawls, A Theory of Justice (1999) (but note that Rawls did not advocate this as a design for international justice); JoHN Rawls, The Law of Peoples (1999) (for which he has been heavily criticized). For a critical analysis of Rawls' theory, see generally Patrick Hayden, Rawls: Towards A Just World Order (2002); Thomas 
However, establishing that the current regime is corrupt, unfair, and highly undemocratic does not mean that its replacement is a simple matter. The Fair Trade regime guarantees a price above the price of production and provided prefinance and calls generally for "fairness," but how can "fairness" be built into a commercial operation?

\section{Constructing an Alternative, How can "Fairness" and Poverty Relief be Achieved?}

A study published in 2005 by Oxfam GB, Novib Oxfam Netherlands and Unilever gives details of a joint research project carried out between Oxfam and Unilever and may give us some clues about how "fairness" can be achieved by commercial operations. ${ }^{117}$ Entitled Exploring the Links between International Business and Poverty Reduction: A Case Study of Unilever in Indonesia, it has important lessons for the Fair Trade movement, the corporate social responsibility movement more generally, and for the assessment of the impact of business on the reduction of poverty and in achieving "fairness." whole operation of an established company from producer to eventual consumer. ${ }^{119}$ Since the Fair Trade movement has as one of its objectives the reduction of poverty and in order to achieve this it must counter some of the embedded cultures of companies which operate to make a profit, this research focused on a forprofit company goes some way to unravel the relationship between doing business and the impact of a firm on poverty in the country where it trades.

The study looked at the impact of the company by tracing the products in which the company traded from production to retail. The influence of the company is thus seen in a holistic light and not only in its effects on the employees or persons most closely associated with the company. The study was, sadly, well situated as the report notes, "despite its abundant natural and human resources, Indonesia has high levels of poverty, with more than $50 \%$ of its population living on less than $\$ 2$ a day. Poor Indonesians face insecure livelihoods, a lack of access to

\footnotetext{
Pogge, Reading Rawls (1989); Dine, Companies, International Trade and Human Rights, supra note 13, at 33-40; Thomas Pogge, Rawls on International Justice, 51 PhiL. Q. 246 (2001).

117. Jason Clay, Exploring the Links Between International Trade and Poverty Reduction: A Case Study of Unilever in Indonesia (Oxfam GB, Novib Oxfam Netherlands, \& Unilever 2005) [hereinafter UI REPORT], available at http://www.oxfam.org.uk/what_we_do/issues/ livelihoods/downloads/unilever.pdf.
}

118. See id.

119. Id. at $26-27$. 
basic services, limited opportunities for economic advancement, and a lack of power to influence their situation." ${ }^{20}$ In 2002, more than 25 percent of children under five were malnourished, 45 percent of the population had no access to clean water, and 15 percent of the population did not live to the age of $40 .{ }^{121}$

Unilever approached the research by styling itself as a "multi-local" company. This is important, as it differentiates it from transnational companies in significant ways. Unilever is signifying that it takes seriously the local context in which it is operating. Truly global companies are much more indifferent to context and will make decisions at headquarters level which are felt to be the correct ones for the group as if it were a single entity, largely ignoring local concerns. Thus, if manufacturing can be carried out more cheaply in another jurisdiction, a global company will move its operations regardless of the impact on the jurisdiction that loses a factory. Unilever Indonesia (UI) claims that such indifference to local concerns is not a factor in decision making. ${ }^{122}$ There is significant evidence that this is the case, not least the response to the financial crises of $1997-98 .{ }^{123}$ However, Unilever's own introduction in the report describes the business as consisting of "two parent companies, Unilever $\mathrm{NV}$ and Unilever PLC, which, together with their group companies operates as nearly as is practicable as a single entity." ${ }^{24}$ The difference between Unilever's foreign direct investment and so-called "butterfly" companies which can move their operations rapidly is that the "local" companies are integrated into the local economies. They are not merely present to exploit cheap labor. Thus, while Unilever "manufactures and markets food and home and personal-care products to consumers in approximately 150 countries around the world. . in 2004 its turnover was 40.4 billion euros and it employed 227,000 people,"125 Unilever Indonesia employs more than 3,000 direct employees and "virtually all management staff is Indonesian, as well as eight out of ten UI board members." ${ }^{126}$ The business is deeply integrated into the Indonesian economy. It is estimated that at least $95 \%$ of Indonesians use one or more UI products every year." 277 Therein lies UI's claim to be a "multi-local"' company. The lessons for fair trade as it moves into the mainstream of retail is that it

\footnotetext{
120. Id. at 12 .

121. Id. at 30 .

122. Id. at 66.

123. In 1997 to 1998 , contrary to the likely response of a globally organized company, UI sought to retain its work force and responded sensitively to local conditions. Id. at 14 .
}

124. Id. at 126.

125. Id. at 125.

126. Id. at 33 .

127. Id. at 13. 
must continue to "think local" and not enter the mindset of global marketers. This will be particularly important in maintaining the indirect impacts of the Fair Trade movement, which have been identified as

- Increased self-esteem

- Better relationships with Northern organizations

- Establishment and support for collective working ${ }^{128}$

All of these indirect impacts are closely related to the definition of poverty established by the Voices of the Poor study by the World Bank, which emphasized that a significant indicator of poverty is the lack of control by the poor over what is happening to them. ${ }^{129}$ In 2003, Murray, Reynolds, and Taylor showed that the visits of inspectors and consumers and the increased attention to farming "promoted renewed pride in coffee farming." This is supported by a number of other researchers. ${ }^{130}$

The better relationships with northern organizations promoted by fair trade has been shown to put producers in a better bargaining position for non-fair trade sales and better ability to access development funds, bank credit and market information generally. ${ }^{131}$

The support for collectives may in some cases encourage increased civic engagement and individual empowerment. However, the evidence is mixed with some studies reporting entrenched group leadership and inefficiencies in structures. ${ }^{132}$ However, it may be that this is only a reflection of universal human frailty and not difficulties inherent in co-operative structures. The lack of power over their own lives was not a matter addressed in a systematic way in the Oxfam-UI report despite its importance as an indicator of poverty. However, the importance of this indicator should not be neglected by those seeking to design an alternative trading system since one result of philanthropy by companies is that, all too often, the poor have "things done to and for" them without consultation. It must also be understood that company decisions are never binding on successors so that a clinic built in any country may not be staffed in the future if the company reverses its policy. A company never has to consult locals before pulling out. A parent com-

128. Nicholls \& Opal, supra note 3, at 211-13.

129. The World Bank, Voices of the Poor, http://web.worldbank.org/WBSITE/EXTERNAL/ TOPICS/EXTPOVERTY/0, contentMDK:20622514 menuPK:336998 pagePK:148956 piPK :216618 -theSitePK:336992,00.html (last visited Jan. 15, 2008).

130. Nicholls \& Opal, supra note 3, at 209.

131. Id. at 211.

132. Id. at 212 . 
pany may put a subsidiary into liquidation for reasons of group efficiency regardless of the local effect. Corporate social responsibility programs have therefore sometimes been criticized as inherently anti-democratic and may even undermine fledgling democracies if the giver of the "good" is not open to influence by a dem-

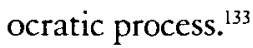

\section{A. Impacts at the Macro-Economic Level}

Despite its claim to be a "local" company, the Oxfam-UI report showed a significant net outflow of funds from Indonesia. ${ }^{134}$ This is usually facilitated by the international trade legal structure which seeks to establish "open" economies with no restrictions on capital flows and the "repatriation of profits." However, the findings at the macro-economic level were by no means all negative. In particular, fewer than 5 percent of senior management positions were held by expatriates, which has implications for technology transfer. ${ }^{135}$ The company also responded responsibly to the financial crisis of 1997-98. These strategies were an interesting mixture of social responsibility and business survival. Recognizing that consumers must be able to afford the products if the business was to survive, UI

- Expanded the number of its products available in small sachets

- Created new, less expensive formulations of popular products, and

- Substituted locally sourced ingredients where possible. ${ }^{136}$

Three other responses to the crisis have lessons for the design of new trading systems. UI renegotiated the margins of profit throughout the supply chain, retained employees and focused on the local market rather than exporting for profit. ${ }^{137}$ The latter two strategies turn conventional wisdom of responses to crises upside down but proved successful.

Of particular importance is the focus of the research on the whole operation of Unilever, from producers of the ingredients of Unilever products, right through to the eventual retail. Four issues stand out:

133. Source Watch, Corporate Social Responsibility, http://www.sourcewatch.org/index.php ? title=Corporate_Social_Responsibility (last visited Feb. 21, 2008).

134. UI Report, supra note 117, at 42, fig. 3.

135. Training of local personnel in the techniques of management is significant in providing development potential within a country. See WatKINS \& Fow LER, supra note 88.

136. UI RePORT, supra note 117 , at 44 .

137. Id. at 14. 
- The concept of sourcing direct from producers

- The impact of advertisements on poor consumers

- The points at which value was captured in the chain of supply and distribution

- The conclusions that fair price and fair practice in commerce are elusive and complex.

\section{B. Direct Sourcing}

Nicholls and Opal count as "Fair Trade Principle One: Direct Trade with Producers." 138 They state that "Fair Trade importers must, wherever possible, buy directly from a farming co-operative, a farming estate, or a local producer group."139 The theory behind this is that it addresses market failures such as

- Exploitative middlemen who rely on lack of competition

- Lack of market information about price and product standards

- Lack of access to credit

- Inability to respond to market forces

- Weak legal systems permitting exploitative labor practices. ${ }^{140}$

However, the Unilever study of a similar initiative shows a more nuanced picture. In 2002, UI initiated a pilot study in relation to Kecap Bango sweet soy sauce. This is based on black soybeans, coconut sugar and brine and the market was growing rapidly. UI moved to buy the ingredients directly from farmers. This was a great success and farmers were anxious to join the scheme for the same reasons that fair trade cites: security of markets, credit supplied by UI and availability of technical assistance via UI funded University schemes. However, Oxfam points out that it also increased dependency on a single buyer and undermined traditional credit and market relationships:

While these systems are exploitative at many levels, they also provide farmers with capital needed for non-farm expenses, for example medical needs, school fees and the cost of weddings and funerals. The new credit system provided through UI is cheaper, more efficient and interest-free to farmers, but it can be used only

138. Nicholls \& Opal, supra note 3 , at 33.

139. Id.

140. Id. at 33-41. 
for expenses related to producing black soybeans. Oxfam considers that farmers risk becoming over-dependent on UI for the sale of the crops, and that they would be hurt by any decline in demand. While producers may benefit from this new system, there are producers and traders in the old supply chain who lose out by exclusion from the new supply chain. ${ }^{141}$

Therefore, there are two matters to be investigated and guarded against: overreliance and the exclusion of middlemen, who, although often said to be exploitative are perhaps unlikely to have an income comparable to a CEO of Tescos and may lose a livelihood entirely by exclusion from the supply chain.

\section{Impact of Advertising}

This aspect may also have lessons for the Fair Trade movement. An important point made by the UI study was that

The debate about the ethical and social implications of extending FMCG $^{142}$ markets to people living on limited financial resources is contentious and not easily resolved. It revolves around some basic questions about wants and needs, whether there is a "right" way for consumers to spend their money and to what extent consumer choice is unduly influenced by advertising. ${ }^{143}$

The report raised a number of issues concerned with competition (there is a danger that big companies may push smaller local ones out of the market) and branding. ${ }^{144}$ However of direct relevance to the Fair Trade movement is the discussion about the role of advertising and the amount spent to promote a brand. Unilever regarded most of its products as basic or essential because they promoted hygiene and healthy living.

However, for Oxfam there remains the question of how a product can be defined as basic or essential when, for poor households, it means purchasing less of something else that is essential for the

141. UI REPORT, supra note 117 , at 72.

142. Fast Moving Consumer Goods.

143. UI RePORT, supra note 117 , at $87-88$.

144. Id. at $19-20$. 
well-being of the household, like health care or education. Oxfam questions whether it is appropriate to market FMCGs aggressively to people living on limited budgets. Advertising runs the risk of turning luxuries into necessities ... It is important to consider-but difficult to measure-to what extent advertising shapes, rather than responds to, consumer values and demand. ${ }^{145}$

It is therefore important to revisit in some detail the impact of fair trade brand advertising on poorer households in the North and consider to what extent the refusal to buy Fairtrade products might become a stigma. Is fair trade aggressively marketed ? ${ }^{146}$

\section{Value Capture in the Supply and Distribution Chain}

The UI Report found that the greatest value-added effect of Unilever's operations was felt closest to the company's own in-house operations. ${ }^{147}$ This shows that it is clearly important to investigate the distribution of values-added in the entire operation, more especially since there has been criticism of retailers for exploiting ethical consumers by pushing up margins on fair trade goods. ${ }^{148}$ This is a damaging criticism which may strike at the root of the trust relationship between the consumer and the Fair Trade movement.

\section{E. Fair Practice and Fair Price}

A significant lesson learned from the UI research was:

We also learned how difficult it is to reach a specific definition of what constitutes 'fair practice' by companies. This issue is not as clearly defined as we would like it to be. . Similarly we debated, but did not resolve, the concept of 'fair price' and the question of how much expenditure on advertising is appropriate as a proportion of consumer prices. ${ }^{149}$

145. Id. at 96 .

146. See Fagan, supra note 54 , at 115.

147. UI RePORT, supra note 117 , at 97.

148. Steve Stecklow \& Erin White, How Fair is Fair Trade? That's Tough to Figure: Confusing Labels Make It Hard for Shoppers to Know Where Money Goes, WALL St. J., June 8, 2004 at A10.

149. UI REPORT, supra note 117, at 21. 
The Oxfam-UI report makes it abundantly evident that the construction of a "fair" system is a complex business. One difficulty in advocating the "integration" of the trust networks which advocate fair and ethical trading is that much more research needs to be done into what an alternative scheme would look like. The detailed research carried out by Oxfam-UI needs to be replicated many times over if the complexities are to be grasped and any replacement scheme constructed. It cannot be designed on the basis of rather vague claims to "fairness." All too often changing the rules means advantaging one impoverished group to the disadvantage of another impoverished group. This is not to diminish the need for ethical decision making in the arena of Trade law but to call for more detailed research in order to construct a radical and detailed alternative to the present corrupt system. In order to achieve democratization of the international regime we need not only consultation, but also the resources to fund serious research into alternatives.

\title{
F. Why Would Democratization Increase Welfare?
}

Tilly argues that

\begin{abstract}
Well being of subjects, on average, increases under democratizing regimes partly because political insulation from inequality, integration of trust networks, and suppression of autonomous power centers are goods in themselves and partly because the popular political voice that results from those processes is a good in itself. On average, people who experience equitable treatment from their governments and/or have direct say in governmental operations gain more satisfaction from politics and display greater willingness to bear burdens for the common good. ${ }^{150}$
\end{abstract}

The World Bank appears to believe that democratization (at least the component of equal opportunity) is a foundation of economic development. ${ }^{151}$ If so, it is surely scandalous that so little attention has been paid to democratization of the international trading regime.

150. TiLLY, supra note 28 , at 184.

151. World Bank, World Bank Development Report 2006: Equity and Development 1-4 (2005). 


\section{Conclusion: What Role Can Law Play?}

This paper argues that the international trading system is both corrupt and a force for de-democratization. The system has a framework of international treaties which have been framed to benefit the powerful and exclude the weak. Law, therefore, has a fundamental role to play in shifting the risks of the international market economy onto shoulders more able to bear them. Such a shift would represent a profound move toward democratization. Such a shift needs to accept the principles espoused by the social and ethical trading movements.

The role of law in the integration of networks was the subject of extensive debate at a seminar in Florence on June 30,2007. This posed the question

how can the law retain its legitimising functions once it is recognised that problem-solving will require the cooperation of politically accountable bodies with societal actors as well as a 'cognitive opening' of legal discourses so as to ensure that scientific expertise and practical societal knowledge can come to bear in decision making. ${ }^{152}$

Teubner argues that "Elements of a civil constitution in the strict sense can be spoken of only once an interplay of autonomous social processes on the one hand and legal processes on the other come about." 153 Blecher calls for law to be open to influence by the social movements. ${ }^{154}$ Hitherto WTO lawmaking has been notoriously resistant to influences other that those advocating free trade. In concluding his book, Tilly argues that

de-democratization occurs chiefly as a consequence of withdrawal by privileged, powerful actors from whatever mutually binding consultation exists, whereas democratization depends on integrating large numbers of ordinary people into consultation. In more complex terms, privileged, powerful elites such as large landlords, industrialists, financiers and professionals have much greater means and incentives than ordinary people to escape or subvert democratic compacts when those compacts turn to their disadvantage.

152. Joerges, supra note 24 , at 7.

153. Teubner, supra note 16 , at 6.

154. Michael Blecher, Law in Movement: Paradoxontology, Law, and Social Movements, in Human Rights and Capitalism, supra note 54, at 80. 
Once they have integrated their lives and life chances into democratic regimes, ordinary people can only with great difficulty detach their trust networks from public politics. ${ }^{155}$

Tilly adds a warning:

if rich states dismantle the redistributive and equalizing arrangements that have grown up within democratic capitalism and rich people disconnect their trust networks from public politics by such means as gated communities and private schooling, we should expect those measures to de-democratize their regimes. Such changes would reinsert categorical inequalities into public politics, reduce the influence of ordinary people over public politics and possibly produce newly autonomous coercive centres of power as well. A decline of relatively broad, equal, binding and protected consultation-de-democratization would be the unhappy outcome. ${ }^{156}$

On the international stage, the growth in inequality, the polarization of wealth and the exclusion from decision making of ordinary people as well as the insulation from regulation of giant corporations reflects a deeply undemocratic regime. It is time to integrate the principles of the social and ethical trading networks and recognize the possibility of the emergence of a new legal order driven by the demand for ethical trading. 